\title{
PROTECTION AND REHABILITATION FOR WOMEN VICTIMS OF VIOLENCE ACCORDING TO INDONESIAN LAW (STUDY ON CENTRAL JAVA GOVERNMENT'S HANDLING THROUGH KPK2BGA)
}

\author{
Ani Purwanti \\ Faculty of Law Diponegoro University, Semarang, Indonesia \\ ani_purwanti81@yahoo.com
}

\begin{abstract}
Based on the report of Indonesia's National Commission of Women Rights, the data of violence against women in 2017 are distributed as 10205 cases of domestic violence (75\%), 3092 cases in community level (22\%), and 305 cases in nation sphere (3\%). Domestic violence is the most occurred violence with 4281 cases of physical abuse (42\%), followed by 3495 cases of sexual abuse (34\%), 1451 cases of psychological abuse (14\%), and 978 cases of economic abuse (10\%). There are 3092 cases of violence in community level, where sexual abuse is placed in the first rank with 2.290 cases (74\%), followed by physical abuse with 490 cases (16\%), psychological abuse with 83 cases (3\%), violence to migrant labor with 90 cases (3\%), and trafficking with 139 cases (4\%). The data in Central Java since 2014 until April 2017 noted 5881 victims of violence, consisting of 4724 female and male victims. The data showed that there are 5163 male and 425 female offenders in the violence cases.

The fulfillment of the rights for women to get the protection and rehabilitation, especially to get quality, comprehensive, and continuous rehabilitation is urgently required. The regulation to protect and rehabilitate women as the victims of violence exists, although the implementation is not enough.

This research used socio-legal approach; an approach overviews the legal and social aspect in observing and finding solution related to the problems in this research.

Legal protection to women as the victims of violence exists in the Law and Regulation in Indonesia (Law of Domestic Violence, Law of Trafficking, Law of Victim and Witnesses Protection), while the rehabilitation to violence against women includes medical services, legal aid services, legal enforcement services, legal resocialization, shelter service, home security services, and counselling services.
\end{abstract}

Keywords: Protection, Rehabilitation, Women, Victims of Violence, Central Java 


\section{Introduction}

Commonly, the conception of violence can be formulated with the indication of abuse of power, inequality, and domination of a party to other parties. ${ }^{1}$ From the abuse of power, people can force and manipulate others which impacts as the violation of integrity and trust to the victims. The abuse of power is usually happened due to the inequality of status, whether between individuals, groups, or nations.

Domestic violence is included in a debate starting from the $18^{\text {th }}$ centuries, where there is a division of people's public sphere to private sphere with non-intervention principle to the private sphere. ${ }^{2}$ Private sphere is deemed natural, free, and can be left. It is deemed as natural which is prone to potential abuses.

The root of the division of public and private sphere influences the position of women. Private sphere is deemed as the maximum room for women, while the public is completely owned by men. Nevertheless, men also have complete power to private sphere. This thing makes women in the subordinated position from men. Since the position is subordinated to men, women seem more inferior than men. This inferiority has been imprinted in the society, supported by the legitimacy concerning philosophy, religious doctrine, and even positive law itself.

The structure of power above has become as historic habit. Thus, violence is susceptible to happen to women. Therefore, the formulation sees that violence to women is the manifestation of power imbalance from men to women which directs to domination and discrimination to women and avoid them to develop their full potentials in the society.

Indonesian women are deemed as susceptive individuals to violence caused by cultural perspective imprinted in the society. This perspective is the patriarchal culture which is rooted deep in Indonesia's people life. This patriarchal culture is the perspective stating that men dominate all role in the social system; as women are neglected from the role they can also do like men. This social role is included in the aspects of social, religion, economy, politics, or culture.

The facts show that violence and injustice to women handled with legal procedures are continuously happening. It is shown by the Annual Report of Indonesia's National Commission of Anti Violence against Women which states that in the post-reformation era, the case of violence against women is increasing annually. The data of Indonesia's Religious Court or

\footnotetext{
${ }^{1}$ R. Valentina Saragih \& Ellin Rozana, Pergulatan Feminisme dan HAM, (Bandung: Women Institute. 2007), p 73

${ }^{2}$ See Carol Pateman, Feminist Critiques of The Public/Private Dichotomy: The Disorder of Women, Dalam Hilaire Barnett (ed)., Sourcebook On feminist Jurisprudence, (London \& Sydney: Cavendish Publishing Limited, 1996), p 143.
} 
Religious Justice System Institution counted that there are 245548 cases of violence. Meanwhile, from the partner institution of Indonesia' National Commission of Women Rights shows 13602 cases from the Service and Reference Unit, a unit which is deliberately made by National Commission of Women Rights to receive the accusation of victims in the office of the commission and from the monitoring division of accusation through mails and electronic mails. ${ }^{3}$

Based on the collected data, the most occurred violence against women is the same as the previous year, which was Domestic Violence/Private Sphere which reached 75\% (10205). The second position was violence against women in community sphere with the percentage of $22 \%$ (3092). Lastly, there was violence against women in nation sphere with the percentage of $3 \%$ (305). In domestic violence/private sphere, the most occurred violence was physical abuse with 4281 cases $(42 \%)$, followed by sexual abuse 3495 (34\%), psychological abuse in 1451 cases (14\%), and economic abuse with 978 cases (10\%). Violence in community-level reached 3092 cases (22\%), where sexual abuse was the highest with 2290 cases (74\%), followed by physical abuse in 490 cases (16\%), and other violence under the amount of 10\%; which were 83 cases of psychological abuse (3\%), 90 cases of violence to migrant labor (3\%); and 139 cases of trafficking (4\%). ${ }^{4}$ The data in Central Java since 2014 until April 2017 noted 5881 victims of violence, consisting of 4724 female and male victims. The data showed that there are 5163 male and 425 female offenders in the violence cases.

In Central Java, there is Regional Regulation No. 3/2009 on Victim of Violence Protection which entrust the existence of Integrated Service Center, as the integrated service provider (from the government and non-government), includes the services of Services of Accusation, medical services, legal aid and enforcement services, social rehabilitation services, repatriation and social reintegration service to assist the victims from gender-based violence and violence against children in Central Java.

From the Regional Regulation, it initiates the establishment of KPK2BGA (Commission of Protection to Victims of Gender-Based Violence and Violence against Children). It is a provincial commission which does the task and exercises of policy and monitoring advocation to the execution of services for victims of gender-based violence in province level and all regency/city in Central Java. Commission of Protection to Victims of Gender-Based Violence

\footnotetext{
${ }^{3}$ Notes of Violence against Women in 2017: Executive Summary, p 1(pdf), (Jakarta: National Commission of Women Rights), accessed on https://www.komnasperempuan.go.id/wp-content/uploads/2017/04/CATAHU-2017Komnas-Perempuan.pdf (Thursday, 31st August 2017, at 04.00 am).

${ }^{4}$ Ibid p 2. 
and Violence against Children of Central Java synergizes with the Officials of Women Empowerment, Children's Protection, Population Control and Family Planning Program) of Central Java as the Regional Government agency which copes the programs of protection to victims of gender-based violence and violence against children in Central Java. Also, it is also related to relevant institutions and Regional Government agencies in province, regency, or city level. This paper shows the findings of how to country, especially government of Central Java through KPK2BGA protects and rehabilitates women as the victims of violence.

\section{Methodology}

This research was a socio-legal research. Through socio-legal approach, it finds patterns, obstacles, and efforts related to the protection and rehabilitation to victims of violence against women based on the influencing legal and social factors.

\section{Result and Discussion}

\subsection{State Guideline based on the Legal System of Indonesia}

County's fulfillment of the rights of the victims of gender-based violence and violence against children is progressing well, whether from the regulation or the program. It must be remembered that the political equality principle among the citizen is the characteristic based on Pancasila and then The 1945 Constitution of Indonesia ${ }^{5}$ It is seen from the implementation of new national and regional regulations related to protection for women and children along with its guidance. The regulation about Women's Protection in Indonesia are enlisted as follows:

1. The 1945 Constitution of Indonesia

a. Article $28 \mathrm{~A}$ states that every people have rights to live and maintain their life.

b. Article 28B section (2) mentions that every child has rights to live, grow, and develop as well as getting protection from violence and discrimination.

c. Article $28 \mathrm{D}$ section (1) states that every people entitle the rights of acknowledgment, guaranteed, protection, and fair legal as well as equal treatment before the law.

d. Article 28I section (1) states that rights to live, rights not to be tortured, rights to have free mindset and conscious, rights of believing religion, rights not to be a slave, rights

\footnotetext{
5 Bayu Dwi Anggono "The Tenure Arrangement of Primary Constitutional Organ Leaders in Indonesian Constitutional System," (Constitutional Review Vol.2 No.1, 2016) p 51
} 
to be acknowledged as individual before the law, and rights not to be prosecuted on retroactive law are human rights which cannot be decreased in all condition.

e. Article 28I section (2) states that every people entitle the freedom of discriminative action and the protection from discriminative acts.

2. The law No. 39/1999 on Human Rights

- Article 45 states that women rights in this law are also human rights.

- Article 71 states that the government is obliged and responsible to respect, protect, enforce, and develop human rights regulated under this Law, other Laws, and International Human Rights Law which is accepted by Indonesia.

- Article 72 states that the responsibility and obligation of the government as stated in Article 71 includes the effective implementation efforts in the fields of politics, economy, social, culture, national security, etc.

- In Chapter I of Elucidation of Law Number 39 Year 1999 regarding Human Rights, it is stated that the regulation regarding human rights is determined based on the United Nation's Declaration of Human Rights, The Convention on the Elimination of All Forms of Discrimination against Women (CEDAW), Convention of the Rights of the Child, and some other international instruments which regulate Human Rights. This law controls the rights to live and rights not to be forced to die, rights to have a family and continue generation, rights of self-development, rights to obtain justice, rights of individual freedom, rights to feel safe, rights to get welfare, rights to participate in governing, rights of women, rights of children, and rights of religious freedom. Besides human rights, it also deals with basic obligation, tasks, and responsibility of the government in enforcing human rights.

3. Law No. 23/2004 o the Elimination of Domestic Violence

- The background of applying this law is

1) that every citizen has rights to feel safe and free from all forms of violence based on the philosophy of Pancasila and 1945 Constitution of Indonesia;

2) that all forms of violence, especially domestic violence is the forms of human rights violation and a crime to human's dignity as well as discrimination which should be eliminated; 
3) that the victims of the violence were mostly women who should get the protection from the nation and the society to be avoided or free from violence or threats of violence, tortures, or actions which demeans their prestige and dignity;

4) that actually, the number of domestic violence is pervasive, while the legal system in Indonesia has not guaranteed the protection to victims of domestic violence;

5) that based on the consideration in point a, b, c, and d, it is required to formulate a Law regarding the Elimination of Domestic Violence;

- Article 1 section 1 states that domestic violence is an action to people, especially women, which causes physical, sexual, psychological misery or suffering, and/or domestic negligence as well as the threats to do the actions, force them, or deprive their freedom which is included as the action against the law in domestic fields.

- Article 1 section 7 states that ministries which handle this are ministries which has task and responsibility of women empowerment.

- In Chapter I of the Elucidation of Law of Elimination of Domestic Violence, it is stated that the upgrade of the law is sided with susceptible or subordinated group, especially women. It is urgently needed as the number of violence is very high, especially in the case of domestic violence. The upgrade of the law is required; since there existing law is not enough and relevant to the development of law in the society. Thus, a regulation regarding the criminal acts of domestic violence is required, because it is specific and unique even though the Criminal Codes has a regulation regarding persecution and decency as well as the negligence to people which requires living and materials.

- Law Number 31 Year 2014 regarding the Protection of Witnesses and Victims The considerations to formulate this law are

1) that the guarantee of protection to victims and witnesses has important roles in the criminal justice system, that the testimony of the witness and victims can be given freely out of fear and threats to reveal criminal acts;

2) that to improve the effort of revealing criminal acts completely, especially for organized transnational criminal acts also requires the protection of witnesses, whistleblowers, and experts;

3) that the provisions in Law Number 13 Year 2006 regarding the protection of witnesses and victims should be adapted to the development of society's need; 
4) that the consideration in point $a, b$, and $c$ raises the needs to formulate Law amending the Law Number 13 Year 2006 regarding the Protection of Witnesses and Victims.

4. Government Regulation Number 4 Year 2006 regarding the Cooperation to Rehabilitate Victims of Domestic Violence

- Article 2 section (1) states that the rehabilitation to victims is done by central and Regional Government institution along with social institution based on their task and functions, including providing required facilities to recover the condition of the victims.

- Article 2 section (2) states that the facility mentioned in section (1) includes:

a. Room for specific service in the police

b. Professional worker

c. Service center and shelter

d. Other infrastructure required for victims' rehabilitation

5. Government Regulation Number 9 Year 2008 regarding the Procedures and Mechanism of Integrated Services to Victims and Witnesses of Human Trafficking

- Article 2 states that the Integrated Service Center are obliged to:

a. provide services and handling as quick as possible to victims and/or witnesses;

b. provide easiness, comfort, safety, and free of charge access to victims and/or witnesses;

c. secure the confidentiality of the victims and/or witnesses; and

d. guarantee the legal justice and assurance to witnesses and/or victims.

- Article 3 mentions that the establishment of integrated services aims to give protection and fulfills the rights of the victims and/or witnesses upon their health's rehabilitation, repatriation, social rehabilitation, social reintegration, and legal aid held by central and Regional Government.

- Article 12 section (1) states that the establishment of integrated services by mayor/regent officials is done along with the cooperation between the institution or other relevant government institution in the area.

6. Central Java's Regional Regulation Number 7 Year 2013 regarding the Children's Protection 
- Article 1 section 25 states that integrated services is a sequence of activities to protect children as the victims of violence, exploitation, wrongdoings, and negligence done collectively by relevant institution as a united controllers, preventive action, medical services, psychosocial rehabilitation, repatriation, social reintegration, and legal aid for children as the victims of violence.

- Article 1 section 30 states that shelter is the temporary home to protect victims with a condition based on the determined operational standard.

- Article 5 section (2) d of the Elucidation from this Regional Regulation states that the provision of infrastructures includes shelter, children's playground, children's health services, education service, handling services, and information and communication network for technological-based children's protection.

7. Central Java's Regional Regulation Number 3 Year 2009 regarding the Protection to Victims of Gender-based Violence and Violence against Children

- Article 6 states that the protection to victims of violence with gender basis and children is helped by:

a. Integrated Services; and

b. KPK2BGA.

- Article 7 section (1) states that integrated services in Article 6 a is formed by Regional Government based on the existing law.

- Article 7 section (2) states that the formation of integrated services as in section (1) has memberships consists of regional government, non-governmental organization, health service provider, legal apparatuses, professionals, assisting volunteers, social worker, religious figures, shelter, and social rehabilitation center.

\subsection{Implementation of KPK2BGA in Central Java}

The existence of KPK2BGA in Central Java is the effort of protecting victims of genderbased violence and violence against children. KPK2BGA is mandated under Article 18 dan 19 of Regional Regulation Number 3 Year 2009 regarding the Protection to Victims of Gender-based Violence and Violence against Children. The roles and authorities of the organization are as follows:

1. Mediating a dispute between integrated service providers to handle the victims of genderbased violence and violence against children; 
2. Doing advocation to policy and programs to protect the victims of gender-based violence and violence against children;

3. Monitoring the process of settlement to the running case;

4. Monitoring and handling the process of integrated services to the victims of gender-based violence and violence against children.

5. Preparing the formulas of policy and programs to protect the victims of gender-based violence and violence against children.

6. Coordinating the dispute between integrated service providers in handling the victims of gender-based violence and violence against children;

7. Developing the system of protection to the victims of gender-based violence and violence against children;

8. Monitoring, controlling, and reporting the protection to the victims of gender-based violence and violence against children.

This is the data of victims and offenders of violence in Central Java:

Data of Victims and Offenders of Violence in Central Java from 2014 to $30^{\text {th }}$ April 2017

\begin{tabular}{|l|l|r|r|r|r|r|r|}
\hline \multirow{2}{*}{ NO } & \multirow{2}{*}{ REGENCY/ CITY } & \multicolumn{3}{|c|}{ VICTIMS } & \multicolumn{2}{c|}{ OFFENDERS } \\
\cline { 3 - 8 } & & \multicolumn{1}{|c|}{$\mathbf{M}^{*}$} & \multicolumn{1}{c|}{ F* $^{*}$} & \multicolumn{1}{c|}{ T } & \multicolumn{1}{c|}{ M } & \multicolumn{1}{c|}{ F } & \multicolumn{1}{c|}{ T } \\
\hline 1. & Banjarnegara Regency & 29 & 107 & 136 & 143 & 5 & 148 \\
\hline 2. & Banyumas Regency & 41 & 183 & 224 & 195 & 31 & 226 \\
\hline 3. & Batang Regency & 51 & 90 & 141 & 127 & 24 & 151 \\
\hline 4. & Blora Regency & 9 & 29 & 38 & 45 & 0 & 45 \\
\hline 5. & Boyolali Regency & 24 & 65 & 89 & 85 & 3 & 88 \\
\hline 6. & Brebes Regency & 20 & 169 & 189 & 187 & 13 & 200 \\
\hline 7. & Cilacap Regency & 45 & 177 & 222 & 192 & 18 & 210 \\
\hline 8. & Demak Regency & 39 & 134 & 173 & 188 & 8 & 196 \\
\hline 9. & Grobogan Regency & 65 & 314 & 379 & 284 & 41 & 325 \\
\hline 10. & Jepara Regency & 41 & 181 & 222 & 101 & 10 & 211 \\
\hline
\end{tabular}




\begin{tabular}{|c|c|c|c|c|c|c|c|}
\hline \multirow[b]{2}{*}{ NO } & \multirow[t]{2}{*}{ REGENCY/ CITY } & \multicolumn{3}{|c|}{ VICTIMS } & \multicolumn{3}{|c|}{ OFFENDERS } \\
\hline & & $\mathbf{M}^{*}$ & $\mathbf{F}^{*}$ & $\mathbf{T}$ & $\mathbf{M}$ & $\mathbf{F}$ & $\mathbf{T}$ \\
\hline 11. & Karanganyar Regency & 8 & 55 & 63 & 66 & 3 & 69 \\
\hline 12. & Kebumen Regency & 63 & 178 & 241 & 198 & 12 & 210 \\
\hline 13. & Kendal Regency & 63 & 209 & 272 & 189 & 10 & 199 \\
\hline 14. & Klaten Regency & 19 & 101 & 120 & 137 & 13 & 150 \\
\hline 15. & Kudus Regency & 11 & 45 & 56 & 69 & 8 & 77 \\
\hline 16. & Magelang Regency & 68 & 188 & 256 & 202 & 15 & 217 \\
\hline 17. & Pati Regency & 35 & 33 & 68 & 60 & 5 & 65 \\
\hline 18. & Pekalongan Regency & 10 & 56 & 66 & 52 & 3 & 55 \\
\hline 19. & Pemalang Regency & 18 & 125 & 143 & 132 & 11 & 143 \\
\hline 20. & Purbalingga Regency & 37 & 46 & 83 & 66 & 0 & 66 \\
\hline 21. & Purworejo Regency & 33 & 110 & 143 & 117 & 6 & 123 \\
\hline 22. & Rembang Regency & 10 & 47 & 57 & 70 & 2 & 72 \\
\hline 23. & Semarang Regency & 9 & 281 & 372 & 302 & 26 & 328 \\
\hline 24. & Sragen Regency & 6 & 71 & 77 & 72 & 2 & 74 \\
\hline 25. & Sukoharjo Regency & 29 & 97 & 126 & 111 & 12 & 123 \\
\hline 26. & Tegal Regency & 48 & 137 & 185 & 153 & 14 & 167 \\
\hline 27. & Temanggung Regency & 20 & 45 & 65 & 56 & 3 & 59 \\
\hline 28. & Wonogiri Regency & 18 & 85 & 103 & 103 & 6 & 109 \\
\hline 29. & Wonosobo Regency & 19 & 346 & 365 & 360 & 13 & 373 \\
\hline 30. & Magelang City & 14 & 82 & 96 & 56 & 9 & 65 \\
\hline 31. & Pekalongan City & 19 & 87 & 106 & 84 & 15 & 99 \\
\hline
\end{tabular}




\begin{tabular}{|c|c|c|c|c|c|c|c|}
\hline \multirow[b]{2}{*}{ NO } & \multirow[t]{2}{*}{ REGENCY/ CITY } & \multicolumn{3}{|c|}{ VICTIMS } & \multicolumn{3}{|c|}{ OFFENDERS } \\
\hline & & $\mathbf{M}^{*}$ & $\mathbf{F}^{*}$ & $\mathbf{T}$ & $\mathbf{M}$ & $\mathbf{F}$ & $\mathbf{T}$ \\
\hline 32. & Salatiga City & 17 & 45 & 62 & 60 & 10 & 70 \\
\hline 33. & Semarang City & 84 & 568 & 652 & 564 & 52 & 620 \\
\hline 34. & Surakarta City & 38 & 127 & 165 & 125 & 8 & 133 \\
\hline 35. & Tegal City & 8 & 45 & 53 & 45 & 6 & 51 \\
\hline & & 1.157 & 4.724 & 5.881 & 5.163 & 425 & 5.588 \\
\hline
\end{tabular}

From the execution of KPK2BGA, it discovered some problems, including:

1. The high number of gender-based violence and violence against children;

2. The improving number of violence against children with most number happens to sexual abuse;

3. Issues of violences are not deemed as an important issue by the government, which impacts the execution of incorrect policy and budgeting in most regencies/cities;

4. Minimum commitment of regional government to protect victims of gender-based violence and violence against children. There are still many regencies/cities which have not integrated the policy of protection to the victims of gender-based violence and violence against children in the planning document (RKPD);

5. There are many regencies/cities which do not have regional regulation handling the protection to victims of gender-based violence and violence against children;

6. The minimum implementation to an integrated service system; since, the institution itself has a weak commitment on its elements.

7. The institution of integrated service center has been established in 35 regencies/cities. However, it still has much functional lack to work as it should be. For example, on its incapability to handle the case which has to be settled in the regency/city, making it influences the function of reference to the integrated service center of the province;

8. There are many integrated service centers in the regencies/cities with no standards of operational procedures and mechanism which make it works with no systematic order;

9. Weak coordination between the elements of integrated service centers, including the coordination of budgeting; 
10. Minimum number of trained workers as stated in the Minimum Service Standard

11. The enforcement of the law is still weak with a bias system to the victims, influencing the rights of the victims, as well as the weak social control in the society.

12. There are many Public Hospital in the regencies/cities which have not been prepared to be the hospital for the victims of violence.

13. There are many regencies/cities which do not have a policy to the exemption of fees for health recovery and visum for the victims of gender-based violence and violence against children.

14. Minimum coordination of conducting preventive actions to violence.

15. Minumum social participation to prevent and protect the victims of gender-based violence and violence against children.

Some efforts done by KPK2BGA of Central Jawa are as follows.

1. Internal Strengthening

2. Mediation of Dispute with In-House Training and Workshop of Mediation to Child Custody.

3. Advocation of policy which consists of

a) Policy Review, Review to the System of Protection for Children as the Victims of Sexual Harassment in Criminal Justice System, Review to the Protection System for Victims of Trafficking for Prostitution, Review of Data Collection to the Victims of Gender-Based Violence and Violence against Children, Review to the System of Protection and Minimizing the Risks to Victims with Disability, Workshop of Formulating the Service Standard based on the Local Condition in Central Java, and

b) Hearing Session

4. The Development of Protection System

5. Monitoring and Control to the Integrated Service which consists of the Monitoring and Control to Integrated Service Center in the Province, Monitoring dan Evaluation of Integrated Service Center in the Regency/City focusing on the Organization and Budgeting, Services of Accusation, Medical Services, Legal Aid Services, Repatriation and Social Reintegration Services, Community Participation, and other preventive actions. 


\section{Conclusion}

1. The regulation of the protection and rehabilitation to women as the victims of violence has been enough with the existence of Constitution, Laws, and Government Regulation and Regional Regulation.

2. The organization of integrated service provider to protect and rehabilitate victims of violence against women and children has existed in 35 regencies/cities in Central Java. Somehow, it is not functioned well with the incapability of handling the cases happening in the society.

Besides, the Integrated Service Centers do not have Standard of Operational Procedures and service mechanism, impacting the service works not in a systematic order.

3. The implementation of the integrated service system in province or Regency/city level has not been optimal due to the weakness of the organization and minimum commitment of its elements. 


\section{References}

Anggono, Bayu, Dwi “The Tenure Arrangement of Primary Constitutional

Organ Leaders in Indonesian Constitutional System," Const. Rev., vol. Vol.2

No.1, 2016

Irianto, Sulistyowati.2006, Memperkenalkan Studi Sociolegal. Buku Obor. Bandung.

Kusuma, Candra. 2013. Penelitian Interdisipliner Tentang Hukum. Epistema Institute. Jakarta.

Pateman Carol, 1996. Feminst Critiques of The Public/Private Dichotomy: The Disorder of Women, Dalam Hilaire Barnett (ed)., Sourcebook On feminist Juristprudence, (London \& Sydney: Cavendish Publishing Limited.

Rahardjo, Satjipto. 2006. Ilmu Hukum. Citra Aditya Bakti. Bandung. 2006. , Hukum dalam Jagat Ketertiban. UKI Press. Jakarta.

Saragih, R. Valentina \& Ellin Rozana. 2007., Pergulatan Feminisme dan HAM, (Bandung: Insitut Perempuan).

Laporan KPK2BGA Provinsi Jawa Tengah (Komisi Perlindungan Korban Kekerasan Berbasis Gender dan Anak), Juli 2017

\section{Regulations}

Constitution of Indonesia (UUD 1945 of the Republic of Indonesia)

Law Number 39 Year 1999 regarding Human Rights

Law Number 23 Year 2004 regarding the Elimination of Domestic Violence

Law Number 31 Year 2014 regarding the Protection to Witnesses and Victims

Government Regulation Number 4 Year 2006 regarding the Cooperation to Rehabilitate Victims of Domestic Violence

Government Regulation Number 9 Year 2008 regarding the Procedures and Mechanism of Integrated Services to Victims and/or Witnesses of Human Trafficking Central Java's Regional Regulation Number 7 Year 2013 regarding the Children's Protection

Central Java's Regional Regulation Number 3 Year 2009 regarding the Protection to Victims of Gender-based Violence and Violence against Children 